\title{
The Politics of Knowledge in 1960s America
}

\section{Citation}

Jewett, A. 2012. "The Politics of Knowledge in 1960s America." Social Science

History 36 (4) (November 2): 551-581. doi:10.1215/01455532-1717172. http://

dx.doi.org/10.1215/01455532-1717172.

\section{Published Version}

doi:10.1215/01455532-1717172

\section{Permanent link}

http://nrs.harvard.edu/urn-3:HUL.InstRepos:11688803

\section{Terms of Use}

This article was downloaded from Harvard University's DASH repository, and is made available under the terms and conditions applicable to Open Access Policy Articles, as set forth at http:// nrs.harvard.edu/urn-3:HUL.InstRepos:dash.current.terms-of-use\#OAP

\section{Share Your Story}

The Harvard community has made this article openly available.

Please share how this access benefits you. Submit a story.

Accessibility 


\section{The politics of knowledge in 1960s America}

Andrew Jewett, Harvard University

\section{Abstract}

This article offers a broad sketch of claims regarding the university's public purpose in the 1960s while noting that a vision of the university as an autonomous forum for moral debate cut across the seemingly insurmountable divide between young radicals and their liberal elders. Read through the lens of educational philosophies, the era's clashes did not simply pit liberal advocates of political neutrality against radical exponents of political commitment. Rather, many radical activists - and some liberals - believed that the university should cut off many of its ties to the wider society to gain a more critical purchase on it. Indeed, activist critics of Clark Kerr's bureaucratic "multiversity" often hewed to a remarkably traditional conception of higher education.

Spring semester, 1965. The Free Speech Movement (FSM) at Berkeley has run its course and achieved its immediate aims. Police cars have been mobilized and immobilized. Students have thrown their bodies on the gears of the machine. Professors have clashed and passed resolutions. Governor Pat Brown has fulminated and called out the cops. Chancellor Edward Strong and President Clark Kerr have retreated. Berkeley's students have won the right to pass out political leaflets and speak on political matters. Yet in the eyes of the FSM leaders, much remains undone. A few tables, speakers, and flyers notwithstanding, business goes on as usual at the university. Students file in and out of classrooms, researchers file in and out of laboratories, calm prevails. From the standpoint of those seeking systemic social change, all seems eerily similar to the spring of 1964, before the movement erupted. The feel of the campus has changed slightly, but American political culture has not.

For many FSM leaders, the next move was obvious: They needed to create a "Free University of California." The FSM Steering Committee members believed that the current state of mass education elevated "the machinery of the educational process" over "the freedom to learn." Yet, they noted, ignorance meant slavery in the complex modern world. They urged each "student-cog" to assert "the right to know" along with something even larger: "It is ours to demand meaning; we must insist upon meaning!" In the vision of the Steering Committee, a free university organized by the students themselves and operating alongside official classes would provide both knowledge and meaning. It would allow students to follow their own paths "when we really get 'turned on' by a great idea, a great man, or a great book," pursuing insights wherever they led rather than hewing to academic boundaries or faculty specialties. The free university would catalyze a nationwide revitalization of liberal education, putting a true institution of higher learning in the place of Kerr's knowledge factory. By creating the free university, the FSM's leaders declared, "we will accomplish a feat more radical and significant than anything the Free Speech Movement has attempted. We will succeed in beginning to bring humanity back to campus." (Free Speech Movement 1965: 211-12, 215-16) ${ }^{1}$

\footnotetext{
${ }^{1}$ This document seems to have originated in the wake of the December 1964 sit-in and appeared in final form as a pamphlet in early January. For a good synopsis of the FSM, see Freeman 2004.
} 
In the wake of the FSM, activists across the nation launched roughly one hundred "free universities" of the type called for in the 1965 statement. (Brubacher and Rudy 1997: 279) These initiatives did not, as it turns out, radically transform American higher education and democracy. But the FSM's embrace of a thoroughly old-fashioned model of liberal education reminds us that the student movements of the 1960s took their shape from more than national politics and personal liberation. They also drew on competing visions of the American university's public purpose and proper organization, visions that cut across lines of bitter political disagreement in often surprising ways. The university loomed large in the 1960s revolts not just because most of the radical dissenters (and many of the conservative ones) called the campuses home, but also because the universities appeared to many of these occupants as the central engine of social transformation. By the end of that tumultuous decade, figures of various political stripes had come to believe that the outcome of the struggle over the universities would determine the future trajectory of American society. ${ }^{2}$

This article offers a broad sketch of claims regarding the university's public purpose in the 1960s while noting that a vision of the university as an autonomous forum for moral debate cut across the seemingly insurmountable divide between young radicals and their liberal elders. Read through the lens of educational philosophies, the era's clashes did not simply pit liberal advocates of political neutrality against radical exponents of political commitment. Rather, many radical activists - and some liberals — believed that the university should cut off many of its ties to the wider society to gain a more critical purchase on it. As is too seldom noted, many critics of Kerr's bureaucratic "multiversity" hewed to a surprisingly traditional conception of higher education.

\section{Two ideals of neutrality}

An important first step in understanding the period is to disaggregate two ideals, which I will call "institutional autonomy" and "scholarly detachment," that critics of the universities frequently conflated under the heading of "neutrality." In many cases, activists who decried scholarly detachment- the adoption of a politically neutral stance by individual scholars - actually embraced the ideal of institutional autonomy in a subtly modified form.

A more orthodox conception of institutional autonomy provided the focal point of criticism for student activists throughout the 1960s. This ideal held that the university failed if it took sides, as an institution, in any intellectual dispute. Yet, proponents typically added, the university offered indirect but uniquely powerful contributions to the wider society by keeping its distance from that society, enabling scholars to pursue unfettered investigations of even the most controversial subjects. Advocates of institutional autonomy wanted professors to choose for themselves how to apply their distinctive skills to matters of pressing social concern, be they normative or technical in character. Otherwise defenders warned, the university would become the mere adjunct of one partisan faction rather than the protector of the entire people. This conception of the university's voluntaristic, indirect relationship to public concerns had become a matter of common sense among academic leaders by the early $1960 \mathrm{~s}^{3}$

\footnotetext{
${ }^{2}$ In addition to the works cited elsewhere, useful treatments of the 1960s include Brick 1998; Gitlin 1993; Isserman and Kazin 2008; and Miller 1994.

${ }^{3}$ Julie A. Reuben (2002: 491) frames this ideal slightly differently as "institutional political neutrality." See also Richard M. Freeland's (1992: 97-119) analysis of a series of late 1960s self-assessments.
} 
By the time the FSM broke out, the debate over the university's public role was swirling around Kerr's Uses of the University (1963), which student activists and faculty radicals took as a kind of negative blueprint. Kerr himself expressed some unease about the character of the university as it stood. He freely admitted that the "great machine" of modern scholarship "turns out its countless new pieces of knowledge ... with little thought for their consequences." Kerr offered a modest call for social engagement, prodding scientists to study political issues, such as population, the nuclear threat, and environmental degradation, and adding that "the social sciences and humanities" could help "add wisdom to truth." Yet these recommendations appeared in the middle of a passage that deemed "middle-class democracy" the "wave of the future" and identified the knowledge machine itself as a force beyond human control: "The process cannot be stopped. The results cannot be foreseen. It remains to adapt." Activists wary of technical rationality could hardly have found comfort in Kerr's identification of "organized intellect" as the "soul" and "central force" of modern society, let alone his claim - clearly designed to parry criticism from the right- that the American universities were "basically conservative institutions." (Kerr 1963: 94, 123-25)

Above all, critics recoiled at Kerr's description of the American university as a "socialized" institution that took its values and cues from the wider society. "The university and segments of industry are becoming more alike," wrote Kerr. "The two worlds are merging physically and psychologically." Meanwhile, a recurrent image in the book portrayed the university as a woman successfully wooed by a free-spending national government. Although Kerr hastened to defend the institution's reputation, calling the bond a "common-law marriage" (ibid.: 50, 90-1), critics seized on an alternative explanation: scholars had prostituted themselves to the powers that be. Activists charged that Kerr's dependent university represented a shocking abdication of responsibility for one of society's key resources: the search for genuine knowledge, unfettered by demands for political conformity (Reuben 2002: 491; Rossinow 2002: 540).

In response to Kerr's vision, activists such as Mario Savio, the FSM's leading voice, reframed the ideal of institutional autonomy in radical terms. As Doug Rossinow (2002: 543) has noted, Savio "was far more attracted to a vision of the university as an ivory tower than was Kerr." Savio believed that a truly autonomous university would profoundly transform both the students and society. He called the FSM itself "a declaration of independence" for "free and independent inquiry" (quoted in ibid.). Of course, his defense of institutional autonomy did not portend a wholesale depoliticization of higher education. Rather, Savio sought a university wherein students and faculty alike, liberated from the pressure to conform to prevailing political norms, could freely explore the deepest problems of the modern era. In the early years of the student movement, many other activists likewise identified institutional autonomy as a valid ideal awaiting realization. They hoped that the universities would achieve a critical distance from prevailing social forces at least long enough to change the surrounding society. These figures generated some of the harshest critiques of Kerr's image of the university as a faithful servant that adopted society's values and ministered to its needs. ${ }^{4}$

\footnotetext{
${ }^{4}$ From a strategic point of view, Kerr's primary misstep in The Uses of the University was to describe the American universities' actual relation to society in the Cold War era rather than offer the usual paean to institutional autonomy, an ideal that stood at some distance from prevailing academic practices. Not that Kerr was the first to describe the university as a faithful servant, of course. He drew on a rhetoric of social service long employed by the leaders of American public universities rather than the discourse of neutrality favored by
} 
The activists' modified version of institutional autonomy, which harked backward to Socrates and forward to a transformed democracy, shone through in the 1965 FSM manifesto, one of the most striking defenses of liberal education penned in the twentieth century. The authors sought restoration rather than revolution. "We Want a University," they insisted. Reverentially capitalizing University throughout the document, they charged that this once-radical entity had been "grotesquely distorted into a 'Multiversity,' a public utility serving the purely technical needs of a society." The manifesto stated that Kerr's factory for bureaucrats left no room for genuine dialogue between students and professors or even between professors themselves. It transformed the unwitting freshman, "a human being seeking to enrich himself," into a mere "mercenary, paid off in grades, status, and degrees." However, the authors found the seeds of a true university latent in the FSM itself: "Jumping off the conveyors, we have become a community of furiously talking, feeling, and thinking human beings" (Free Speech Movement 1965: 212-14).

If the early student activists often embraced a version of institutional autonomy, they utterly rejected the ideal of scholarly detachment. Here, the question was whether the individual scholar, rather than the university as a whole, should take sides in the controversies of the day. Student activists repeatedly singled out scholars' professional selfconception as a key determinant of the undergraduate experience. As Tom Hayden (2005a: 49) wrote: "The questions we might want raised - what is really important? can we live in a different and better way? if we wanted to change society, how would we do it? - are not thought to be questions of a 'fruitful, empirical nature,' and thus are brushed aside" by the faculty. The FSM leaders sought in their 1965 statement to apply "the relentless hammerblows of conscience" to the "ramparts of rationalization which our society's conditioning ha[s] erected about our professors' souls" in the hope of rendering the university "a loving community" (Free Speech Movement 1965: 210). Radical students routinely insisted that value commitments inextricably shaped research and often also contended that scholars could achieve consensus in what seemed purely subjective realms of value. From opposite ends of the political spectrum, Hayden (2005a: 51) and the conservative activist M. Stanton Evans agreed that empirical inquiries implicitly took their form from "orienting theories" and "basic principles," especially "conceptions of human beings, human relationships, and social systems." Yet, they complained, modern views of knowledge denied the relevance of such concerns and thereby impoverished public life. Whereas earlier progressives had been "plagued by vision without program," Hayden wrote, "our own generation is plagued by program without vision." He added, in the face of what he saw as a prevailing moral relativism, that value judgments were hardly "beyond discussion and tentative determination," despite the lack of pat "formulas" or "closed theories" in that realm (ibid.: 50-1; cf. Evans 1961: 236-39).

\section{Conformity and authenticity}

Several streams of thought informed the FSM activists' embrace of liberal education. Like other student radicals, they drew on multiple, overlapping discourses of authenticity that championed the integral human person against the "faceless and terrible bureaucracies" of the modern age (Paul Potter, president of Students for a Democratic Society [SDS], quoted in Kazin 1998: 190). Most prominent in their repertoires were the humanistic

prominent scientists. Berkeley's unusual status as both a public institution and a leading research university placed it at the intersection of these potentially conflicting discourses on the university's public purpose. 
psychology of Carl Rogers and Abraham Maslow, the existential theology of Paul Tillich, the radical strain of Catholic social thought represented by Michael Harrington, and the more diffuse but remarkably widespread preoccupation with "conformity" that had propelled books such as David Riesman's Lonely Crowd (1950) and William H. Whyte's Organization Man (1956) to the forefront of the national consciousness in the 1950s. All of these distinctly non-revolutionary modes of social criticism identified liberal education as a leading antidote to inauthentic modes of being. Whyte (ibid.: 447), for example, argued that Americans could halt the spread of administrative values by wresting their schools and universities away from the avatars of personal adjustment and instituting a "rigorously fundamental" education. Other critical humanists likewise insisted that a truly liberal education, one that allowed students to openly discuss deep-seated normative questions, could stock the nation with critically engaged citizens. ${ }^{5}$

Hayden strongly echoed these humanist currents in writing the Port Huron Statement, the 1962 manifesto of the SDS. He called for a true democracy based on humanity's "unrealized potential for self-cultivation, self-direction, self-understanding, and creativity." Yet such a democracy, he noted, would appear "only when a love of man overcomes the idolatrous worship of things by man." Like Savio, Hayden argued that the universities could produce this transformation of cultural consciousness by fostering open inquiry. He declared autonomous learning to be intrinsically radical and implored scholars to choose human needs over corporate and military needs, thereby turning the universities into a "source of social criticism and an initiator of new modes and molders of attitudes." Indeed, the Port Huron Statement identified the university, reconstituted as a "community of controversy," as the key to a viable left strategy: "Any new left in America must be, in large measure, a left with real intellectual skills, committed to deliberativeness, honesty, [and] reflection as working tools." Hayden insisted that the university, the only remaining social arena in which "individuals of nearly any viewpoint" could find a venue, would play a central role in breaking through the crust of a stifling, bureaucratic society (Hayden 2005a: $52-3,60,166-67)^{6}$

A number of texts and figures helped connect these postwar discourses of autonomy and authenticity to the educational concerns of student activists. Among the most important was Paul Goodman's Community of Scholars (1962). Goodman, who had been exiled from academe after several trysts with male students, nevertheless saw in the universities the best hope for the recovery of anarchism - a social order based on "face-to-face self-governing communities," of which the university represented the only remaining example. He interpreted the survival of an essentially medieval institution into the present age as proof that the encroaching forces of "modern co-ordinative management" could not handle one of modern society's main functional tasks: that of inducting students into what Immanuel Kant had called "universal culture." Goodman described the university as the last line of defense against the managerial invader. Yet the virus had made major inroads even there, with the

\footnotetext{
${ }^{5}$ On these discourses of authenticity, see especially Horowitz 2004; Jamison and Eyerman 1994; and Rossinow 1998.

6 "A new left must transform modern complexity into issues that can be understood and felt close-up by every human being," Hayden (2005a: 167) elaborated. "It must give form to the feelings of helplessness and indifference, so that people may see the political, social, and economic sources of their private troubles and organize to change society." New knowledge, and not just "aching stomachs," would drive reform. The SDS members also reached back to John Dewey's thought in constructing their vision of participatory democracy. Hayden (2005b: 6) noted this connection.
} 
result that the "powerful and importantly independent" colleges existed in relative harmony with an utterly debased society, rather than producing the "continual and electric clash" befitting their autonomous position. "The scholars are not acting, not being men," Goodman lamented, "and therefore within the communities of scholars, there is very little education or growing up." According to Goodman, the spread of the "administrative mentality" into the very citadel of independent thought explained why there was "so much inane conformity" despite "so many centers of possible intellectual criticism and intellectual initiative." Calling the modern universities "little models of the Organized System itself," he urged scholars to rebuild the "wall" separating these institutions from the larger society until such time as the latter became "an international city of peace." In the lengthy interim, he insisted, the true university's "humanism" would render it alien and subversive (Goodman 1962: x, 3-5, 7-8). ${ }^{7}$ Goodman's vision of the ideal university provided a key source of inspiration for the free university movement and other expressions of student activism (Brubacher and Rudy 1997: 279).

\section{Radicalization}

By the late 1960s, however, students on the left had begun to doubt that free inquiry could ever be attained under current conditions. In the SDS, for example, the leftward turn of 1966-1967 brought an intensification of attacks on the universities. Many student radicals came to regard the much-touted institutional pluralism of American society as a sham and thus the image of an autonomous university as a dangerous illusion. From this angle, the division of social power celebrated by Kerr appeared to be a mere façade masking what $\mathrm{C}$. Wright Mills (1956) had called an "interlocking directorate": a small, homogeneous elite whose members filled all of society's leadership slots. ${ }^{8}$

These later student activists found the ideal of institutional autonomy maddeningly quietist and thus implicitly partisan. These radicals embraced Kerr's ideal of social service without his narrow, materialist definition of what the community needed. Real social service, they believed, would take the form of helping an oppressed people throw off the yoke of a racist, capitalist, and imperialist elite. For example, Carl Davidson (1971 [1967): 133) and others in the SDS hoped to assist Third World revolutionaries via "the disruption, dislocation and destruction of the military's access to the manpower, intelligence, or resources of our universities" (see also Kazin 1969: 649). Eschewing the ideal of open inquiry as a farce, critics of this stripe sought to turn the universities into training grounds for popular movements at home and abroad. ${ }^{9}$

Yet a commitment to institutional autonomy remained strong in many quarters even as a growing number of activists who favored liberal education as a means of change concluded, with their laboratory-smashing peers, that the roadblock to social change was the capitalist-imperialist machine itself and not just a faulty understanding of the university's social role. David Horowitz, still in his radical phase, came to believe in the mid-1960s that those holding the purse strings kept professors on too short a leash for them to contribute

\footnotetext{
${ }^{7}$ Goodman 1964 extends his critique.

${ }^{8}$ For a recent analysis of Mills's book, see Geary 2009, esp. 151-162.

${ }^{9}$ John R. Searle (1971: 15) argued that the radicals' "identification of the university as a source of evil" reflected a "holistic ideology" that held that "the structure of power in America is a seamless fabric" and implied that "a blow struck at the university is a blow at the very heart of racism (militarism, imperialism, oppression) in American life."
} 
constructively to social change. Contending that "institutional research on any significant scale is possible in this country only when initiated and funded by the ruling class," Horowitz blasted the universities' failure to provide "intellectual room for a critical dialectic to develop" (quoted in Roberts 2007: 108). ${ }^{10} \mathrm{He}$ and many like-minded figures hoped to break the power of the ruling elite, restoring the universities' lost autonomy and publicmindedness.

Ironically, these advocates of critical dialogue could find in their ideal of institutional autonomy a potent argument for the temporary disruption of academic business as usualshutting down classes, shouting down speakers, and the like. Herbert Marcuse's essay "Repressive Tolerance" spelled out the reasoning. In a "totalitarian democracy," Marcuse wrote, where "the "marketplace of ideas' is organized and delimited by those who determine the national and the individual interest," the "exercise of civil rights by those who don't have them presupposes the withdrawal of civil rights from those who prevent their exercise." To restore the "conditions under which tolerance can again become a liberating and humanizing force," he continued, the dispossessed and their advocates would need to facilitate "withdrawal of tolerance from regressive movements before they can become active," by placing sharp limits on the freedom of "thought, opinion, and word." Arguing that the West remained in essentially the same position as Adolf Hitler's enemies during the 1930s, Marcuse insisted that only temporary abridgements of democratic rights could clear the way for the restoration of substantive democracy (Marcuse 1969 [1965]: 99, 110-11; cf. Anonymous 1971 [1969]: 59-60).

\section{The liberals}

Liberal defenders of institutional autonomy understood that ideal in a very different fashion than did most student activists. They generally believed that the universities had already achieved a substantial degree of independence, the preservation and expansion of which offered the only hope of social health. Society, these liberals insisted, would always need the kind of independent criticism that only autonomous universities could provide. Indeed, many liberals soured on the student movement precisely because it began to violate the ideal of free and open discussion. When activists started shouting down professors and speakers whose views they rejected, and eventually shutting down buildings and entire campuses, liberal professors responded with a litany of calls to preserve the institutional autonomy of the universities. What many activists viewed as the beginning of true dialogue on the campus, many liberals viewed as the end of open debate - a death knell for the university and for society itself.

The historian Richard Hofstadter's 1968 commencement speech at Columbia University exemplified the argument for institutional autonomy. Coming on the heels of an eight-day occupation of President Grayson Kirk's office by students protesting the university's military ties and its plan to build a gym in an impoverished neighborhood, the ceremony featured a massive student walkout just as Hofstadter began to speak (McCaughey 2003: 434-61). Himself a former leftist, Hofstadter discerned an existential threat to the university in what he took to be the students' demand that the institution commit itself corporately to one of several contending political forces. It was "of the very essence of the conception of the modern university," he told his suddenly diminished audience, "that no

\footnotetext{
${ }^{10}$ Horowitz had earlier believed that the university's support for free intellectual exchange rendered it "the last refuge of true democracy in America" (quoted in Roberts 2007: 95).
} 
one is authorized to speak for it." Hofstadter insisted that the university represented "a citadel of intellectual individualism" in an "age of rather overwhelming organizations and collectivities." Indeed, he found it extraordinary that a society would "support and sustain institutions part of whose business it is to examine, critically and without stint, the assumptions that prevail in that society." Hofstadter feared that if student activists shortcircuited this open dialogue, even in the name of admirable political ideals, they would undermine the American people's fragile commitment to independent criticism as a social good (Hofstadter 1968: 583-85).

The specter hovering over Hofstadter and many other liberal advocates of institutional autonomy was McCarthyism, a fresh and painful memory for them but only a vague childhood impression for their students. The hammer of Red-baiting came down particularly hard on scholars in the 1950s, because conservatives identified university faculties with the "creeping socialism" of Franklin Roosevelt's New Deal. After Joseph McCarthy's meteoric rise to power, he and other critics of elite, Northeastern "eggheads" singled out professors - especially natural scientists, social scientists, and philosophers-for public shaming. Many members of these heavily left-liberal disciplines responded by claiming that they did not seek to dictate or even speak to questions of value (Schrecker 1986; Wang 1999; McCumber 2001; Reisch 2005). In the 1960s liberal advocates of political neutrality carried forward this campaign to parry criticism from the political right, which still struck many scholars as the main threat. The American people's decision to extricate itself from McCarthyism seemed a minor miracle to such scholars, who saw in that act of collective will a dim recognition of the social importance of unfettered inquiry. Positioning themselves as the loyal opposition to capitalist society, these liberals feared that student radicals would wake once again the sleeping beast of right-wing anti-intellectualism and bring the nascent experiment in institutional autonomy to a hasty close (Brick 2006: 13; Brown 2006: 215).

Thus whereas many students viewed the liberal ascendancy of the Kennedy years as evidence of American society's endemic conservatism, Hofstadter saw in it a "momentary balance of forces in society" that could easily swing back toward reaction. For this reason, he deplored the radicals' attempt to use universities as levers for direct political change. These institutions, he acknowledged, "do share in, and may even at some times and in some respects propagate, certain ills of our society." However, Hofstadter continued, the perception that "the best way to change a social order is to start by assaulting its most accessible centers of thought and study and criticism" reflected both "a complete disregard for the intrinsic character of the university" and a strategically disastrous failure to recognize its precarious social position. Hofstadter urged student activists to protect "this center of our culture and our hope" by acknowledging their own fallibility and dedicating themselves to social change through "orderly and peaceable discussion" within and without the universities. "If an attempt is made to politicize completely our primary centers of free argument and inquiry," he warned, the universities would surely be "reduced to centers of vocational training." The conservatives would win outright if students exposed the flame of open inquiry to the fierce winds of politics (Hofstadter 1968: 584-86, 589). ${ }^{11}$

\footnotetext{
${ }^{11}$ In general, liberals insisted that modern American society should be compared to the societies of other times and places, not what one bluntly called "a non-existent ideal" (Maxwell 1969: 338; cf. Kerr 1964: 165; Searle 1971: 62, 157). "My standard of comparison is not how much worse things used to be," Harrington (1997 [1962]: 18) retorted to such views. "It is how much better they could be if only we were stirred." Of course,
} 
The Berkeley philosopher John R. Searle (1968) spoke for another group of faculty liberals who feared an emerging "left McCarthyism" more than conservative threats. Searle, who would later stir up the national turmoil over "political correctness," sympathized far less with left-wing students than did the former socialist Hofstadter. Perhaps recalling the post-1964 radicalization of the Berkeley movement, which had turned him against activists he had previously supported, Searle accused the students of seeking to turn the university into "a service station for the radical movement" rather than recapturing "the traditional humanist ideal of knowledge and understanding as valuable in themselves." Indeed, he identified the student movement's leading features as "its anti-intellectualism and its hostility to the university as an institution." Under these tendencies, Searle discerned major psychological instabilities generated by the combination of economic prosperity and permissive child-rearing practices. Comparing campus officials to Romans facing "a bunch of nutty Christian fanatics," Searle complained that most faculty liberals failed to understand the essentially religious nature of the student movement. Its leaders, Searle insisted, staged symbolic confrontations with radical evil for their own sake rather than pursued practical ends through instrumentally rational means. For this reason, university administrators could not simply broker deals with them. In the end, the students did not actually want to win, let alone negotiate a compromise (Searle 1971: 5, 49, 70, 73, 155).

As an antidote, Searle urged administrators and faculty to reassert a potent philosophy of liberal education that could replace the students' irrational quasi-religion. $\mathrm{He}$ explained that the needed faith would identify the university as "an aristocracy of the intellect" and charge it with "imposi[ng] ... adult standards of rationality and intelligence on the students." Searle believed that this philosophy of education would enlist and redirect the students' religious longings, provided that the faculty understood that intellectual development, and truth itself, included "insight and understanding, artistic creativity, aesthetic sensibility, and moral discrimination" as well as cognitive rationality. Placing cultural agency squarely in the hands of the faculty, Searle traced the rising generation's susceptibility to radicalism largely to "the fact that they are so savagely uneducated." $\mathrm{He}$ insisted that "the touching, moving, and utterly sincere imbecility" of activists" "religious outbursts, and the deeply felt utopian vision that underlies them," could be met only by "a relentless exposure of their preposterousness" through the promotion of the truth in all its fullness (ibid.: 216, 223-24, 241). Searle favored a paternalistic model of higher education that combined institutional autonomy with a broad, multifaceted conception of truth.

A third group of liberals endorsed institutional autonomy but found the existing system utterly debased by the kinds of social ties Kerr celebrated. Robert M. Hutchins, former president of the University of Chicago, spoke for a group of liberals who wanted to restore the centrality of the core liberal arts, deepening the undergraduate program by highlighting the systematic discussion of values. Hutchins deemed the current model of higher education "cannibalistic"; the American university had swallowed far too much of the surrounding society to pose a real challenge to it. "If it is to fashion the mind of the age

only part of the liberals' resistance to systematic change stemmed from their view that the American polity featured "a conservative right and a liberal left competing for the votes of the mostly conservative silent majority," as Searle (1971: 145) put it. Many liberals also shared what Howard Brick (2006) has called a "postcapitalist" belief that organized modern societies stood poised to break through capitalism to something more like socialism without the need for revolutionary violence. A particularly breathless expression of the postcapitalist sensibility is the "Triple Revolution" statement of 1964, reprinted in Fromm 1965b: 441-461. 
and not be fashioned by it," Hutchins (1967: 7) insisted, "the university must be a center of independent thought and criticism, an autonomous thinking community." Similarly, the many self-assessment exercises produced by academic organizations in the late 1960s and early 1970 s typically held that the universities had moved too far in the direction of social service and neglected their more traditional academic functions (Freeland 1992: 112). In these instances, commentators used the ideal of institutional autonomy to criticize the university system, not to defend it.

Yet Hutchins remained optimistic about the prospects for change, and joined Searle in placing cultural power in the hands of the faculty. "I don't think the case is difficult to make," he stated, "that a democratic society is not likely to survive, at least not likely to survive easily, in the absence of independent centers of criticism, independent centers of thought, and independent intellectual communities." In Hutchins's view, the real obstacle to reform was not any conservative bent or anti-intellectualism among the public but "the departmental system and the reward system of university professors," against which he had waged a concerted battle since his arrival at Chicago. Indeed, he attributed both "the peculiar attitudes of the public" and "the dissatisfaction of the students" to the faculty and administrators' inability to articulate a "rational conception of what a university is" (Hutchins 1970). Goodman (1962: 9) likewise combined a dark view of the present scene"I am a partisan of the scholars and we are losing badly," he wrote - with optimism about the prospect of professors changing their tune and thereby changing society.

\section{The politics of truth}

Within disciplines and departments, the issue of institutional autonomy took a backseat to that of scholarly detachment. "We are angry," wrote Linda Gordon and several other feminist historians. Yet, they continued, "we do not believe that that interferes with the scholarly value of our work. To be scholarly does not mean to be unemotional or to pretend to be uninvolved in the issues at stake" (quoted in Reuben 2000: 87). Other faculty members erected a high wall between politics and knowledge, insisting that the "politicization" of scholarship squeezed out the truth altogether. Debates over scholarly detachment split many disciplines down the middle in the late 1960s and shaped emerging programs in women's studies, African-American studies, and other new fields. Events such as the 1968 Third World Strike at San Francisco State College revealed strong concerns about the deleterious effects of scholarly detachment on both the research and the teaching functions of the university (Bloland and Bloland 1974).

Radical scholars had powerful reasons to chafe at the ideal of scholarly detachment. Those holding the reins of power, especially in the rechristened "behavioral sciences," often combined extravagant claims of neutrality with thinly veiled or frankly avowed support for a broadly utilitarian form of liberalism. They insisted that, in the public spaces of a democracy, citizens should bracket both immediate self-interest and controversial religious and ideological beliefs and seek instead to promote the material and psychological welfare of the citizenry as a whole, as defined by social scientists. (Herman 1995) To be sure, many establishment liberals embraced the normative dimension of politics. Even Kerr (1964: 164) criticized Americans" "embarrassment about the expression of moral seriousness" and lauded commentators for speaking freely of "love, courage, self-development, commitment, meaning," and similar concepts. Yet his application of the vocabulary of psychological 
health to the political sphere did much of the same political work performed by claims of value-neutrality. His analysis ruled Marxism out of bounds, along with traditional Christianity and other comprehensive worldviews that defined morality for so many Americans. Young radicals and conservatives alike saw hypocrisy in liberal scholars' tendency to dismiss "ideology" while advocating extensive programs of social engineering on behalf of New Frontier liberalism.

As the war in Vietnam escalated, scholarly detachment took on a new dimension for students and faculty on the left. Scientists' disavowals of responsibility for the uses of their research rang hollow to critics, given that defense dollars and military secrecy had penetrated into remote corners of fields such as physics, anthropology, and even philosophy. "What I'm designing may one day be used to kill millions of people," stated one graduate student during a protest against military-sponsored research at the Massachusetts Institute of Technology (MIT) in 1969. 'I don't care. That's not my responsibility. I'm given an interesting technological problem and I get enjoyment out of solving it" (quoted in Leslie 1993: 238). A Stanford laser scientist arrived at much the same point via a different path. "Nobody likes [Department of Defense] support less than we do," he allowed. Yet "when the military supports everything, they're the people who come around with the problems, and so you think about those problems" (quoted in ibid., 181). Antiwar critics rejected both versions of this claim of distance from military applications, insisting that the choice of a career in research did not eliminate or supersede one's moral responsibilities as a human being.

If "relevance" was the key term for undergraduate activists - at least in the days before "revolution"_- "responsibility" filled that niche for left-leaning professors and graduate students. Mills's call for a "politics of truth" in the face of official lies resonated powerfully with scholars seeking to bring critical perspectives into their disciplines. While Mills's Power Elite (1956) taught activists to see through claims of decentralized power, his Sociological Imagination (1959) challenged the empirically sterile grand theories and decontextualized empirical studies that critics associated with the behavioral science model (see also Geary 2009: 168-78). Echoing Mills, the MIT linguist Noam Chomsky famously declared in "The Responsibility of Intellectuals" that scholars could neither ignore nor condone the financial and ideological structures supporting their work. "It is the responsibility of intellectuals to speak the truth and to expose lies," he wrote forthrightly (Chomsky 1968 [1967]: 256). Chomsky pursued an Enlightenment-inspired strategy of removing the public's ideological blinders, tearing away the veil to reveal the naked workings of power. Radical scholars in the Chomskyan vein assumed that the truth would inevitably resonate in the public mind if only it could be extricated from the fog of capitalist-imperialist deceptions. $^{12}$

This "politics of truth" strategy informed several influential analyses of American power developed by activist scholars in the late 1960s. One prominent theory identified "corporate liberalism" as the dominant ideology in modern America. As the historian Ronald Radosh and other advocates of this interpretation insisted, the real enemy was not conservatives but rather business-friendly liberals - Kerr's precursors - who had turned the university into a dependent arm of capitalism (Roberts 2007: 63). Another theory identified

\footnotetext{
${ }^{12}$ Ironically, given Chomsky's lifelong campaign to demonstrate the centrist biases at work in the New York Times, that newspaper offered a similar critique of academic expertise, albeit without the anti-imperialist edge (New York Times 1965).
} 
students at leading research universities as the core of a "new working class" of highly educated but profoundly oppressed white-collar workers. Inverting a recent wave of plaudits for the "knowledge economy," Savio and other FSM leaders, as well as the SDS national secretary Greg Calvert, joined Goodman in declaring undergraduates at top universities "the major exploited class" in modern America. (Calvert 1970 [1967]; Free Speech Movement 1965: 208; Goodman 1965; Rossinow 2002: 541) Theorists of the new working class, like those hewing to the corporate liberalism line, sought to catalyze social transformation by revealing to students the fact of their oppressed status.

Other advocates of the politics of truth identified the United States as a caste system rather than a capitalist behemoth. "Students are niggers," argued Jerry Farber, a professor of English literature at California State College at Los Angeles. Undergraduates occupied "an academic Lowndes County," he wrote, where they ate in "separate and unequal dining facilities" and suffered under an "anti-miscegenation law" barring "student-faculty lovemaking." Despite Farber's shock-inducing rhetoric ("At my school we even grade people on how they read poetry. That's like grading people on how they fuck"), his ideal of education largely echoed that of Goodman. Farber's widely read essay again tasked faculty with inducting students into the ranks of independent-minded adults. He insisted that students already possessed the power they needed to fundamentally transform the university, being held back only by mental strictures incorporated from the larger culture. "For students, as for black people, the hardest battle isn't with Mr. Charlie," Farber wrote. "It's with what Mr. Charlie has done to your mind." Farber viewed the students' potential sphere of action as virtually unbounded if only they could be shown the truth of their oppression (Farber 1970 [1967]).

As Chomsky's essay illustrates, this debunking approach stood in an ambiguous relation to the ideal of scholarly detachment. Advocates of a politics of truth decried existing claims to objectivity on the grounds that American scholarship was deeply compromised by its complicity with social domination. Chomsky identified "the desperate attempt of the social and behavioral sciences to imitate the surface features" of the natural sciences as a major source of the public's reluctance to recognize America's imperialist ambitions. Scholars, he insisted, must go beyond "technical" and "tactical" problems to debate matters of "principle," including "moral issues and human rights," and even "the traditional problems of man and society, concerning which 'social and behavioral science' has nothing to offer beyond trivialities." The contemporary "cult of the experts," with its assumption that moral formation could be left to the churches and philosophers, did not provide a sound basis for national policy, in Chomsky's view. He issued a potent materialist critique of the "self-serving" worldview of academic liberals, connecting their uncritical outlook and allergy to ideology to "the fact that they play an increasingly prominent role in running the Welfare State” (Chomsky 1968 [1967]: 271, 274, 276).

At the same time, Chomsky sought a deeper form of neutrality. He believed that intellectuals, speaking on behalf of humanity, could utter the unvarnished truth. In an age when the "propaganda apparatus" had buried reality so deeply that only sustained research could reveal it, Chomsky wrote, intellectuals needed to "confront government pronouncements with fact" and "analyze actions according to their causes and motives and often hidden intentions." Despite his politically radical conclusions, Chomsky shared a conception of knowledge with the defenders of scholarly neutrality. Speaking freely of "facts," "truth," and "the historical record" and ceding ground to no one on the "traditional 
intellectual values," Chomsky insisted that intellectuals discovered knowledge rather than made it. Inevitably, he added, scholars "remote from the exercise of power" managed to penetrate the veil of propaganda, whereas the so-called experts, with their "Washington contacts" and easy access to power, became snared (ibid.: 257, 255, 271, 266). In an important sense, Chomsky's politics of truth pointed back to versions of scholarly detachment and institutional autonomy.

\section{Cultural turns}

Whereas Chomsky packed a vast body of normative political argumentation into his conception of "truth" and deemed it objective, other critics defended similar political claims on openly normative grounds and attacked the stance of scholarly detachment itself. By the late 1960s many young radicals had concluded that the ideal of detachment conflicted directly with personal authenticity: If genuine selfhood required political engagement and political engagement conflicted with scholarly neutrality, as the liberals kept insisting, then neutrality could not be a responsible position for the scholar. These figures refused to follow Chomsky in substituting a "higher neutrality" for the current, spurious version, although that strategy echoed in their work. Instead, they stressed the intrinsically normative character of all knowledge, drawing out in particular the judgment against social inequality implicit in the works of Chomsky and other advocates of a politics of truth. Rather than target official lies, they challenged what they took to be the disabling assumption that prevented scholars from speaking their minds and providing social leadership - the postulate of valueneutrality, derived from a relativistic culture that denied the very existence of normative obligations. Critics of this persuasion pitted a culture of commitment against a culture of detachment.

In targeting value-neutrality this way, left critics had company. Academic humanists had long criticized social scientists in just such terms, and they continued to do so in the 1960s. The Columbia University historian Jacques Barzun charged in 1966 that behavioralism was "secreting into the larger society something akin to a poison." Under its aegis, Barzun claimed, a mechanistic conception of reality, once "simply an intellectual scheme," had become "an image of our inner life" (Barzun 1966: 11, 13; cf. Barzun 1964). Since the 1950s leading American conservatives had also challenged the possibility of neutral, non-normative social knowledge. According to the Jewish commentator Will Herberg (2008: 4-5), a former Marxist who had gravitated to the conservative National Review by the late 1950s, social scientists' illegitimate extension of a technological orientation into the sphere of social interaction had undermined the very possibility of meaningful action, turning human beings into mere cogs in vast projects of social engineering. Even liberal social scientists on occasion took up cudgels against scholarly detachment and technocratic manipulation, as did the Berkeley political scientist Floyd W. Matson in The Broken Image (1964). ${ }^{13}$

Of course, these critics offered divergent solutions to modern society's meaning deficit. Whereas Herberg (2008: 7) looked to "the divine or the natural law" underpinning the great tradition of the West, radical critics of scholarly detachment located their normative ideal in the future. The term "human" carried immense argumentative weight in

\footnotetext{
${ }^{13}$ Goodman (1962: x) articulated an assumption common among critics of scholarly detachment when he argued that the social sciences merely delineated the contours of the current society whereas the arts and humanities enabled a comparative assessment by revealing other ways of life from other times and places.
} 
their writings. It signified an ideal of individual liberation that extended far beyond material comfort into the emotional and spiritual realms. Thus SDS president Paul Potter charged the universities and other institutions with elevating "material values" over "human values" by subordinating individuals to "faceless and terrible bureaucracies" (quoted in Kazin 1998: 190). In fact, the student Left and the student Right attacked liberal social engineering in formally similar terms. Although Hayden's free spirit hardly resembled Evans's inheritor of Western civilization, both young activists adopted a Romantic contrast between live, vital, organic personhood and the liberals" "mechanistic" values and organizations. ${ }^{14}$ Ignoring or disavowing the strong public-private split that informed postwar liberalism, these critics saw in it a thoroughly materialistic worldview that denied essential aspects of the human person.

Marcuse's writings, which built on Martin Heidegger's politically ambiguous critique of modernity's technological orientation, connected the impersonal, deadening character of contemporary culture to the question of scholarly detachment in a manner that resonated powerfully with American activists. Marcuse's (2002 [1964]) One-Dimensional Man, which introduced many young radicals to the theories of the Frankfurt school, argued that the concept of neutral knowledge reflected a culture-wide elevation of means over ends that prevented the inhabitants of the modern world from recognizing their complicity in their own oppression. Despite Marcuse's own intentions, his writings reinforced a nascent tendency among radical scholars to take as their primary target the ideal of detachment (under the heading of "objectivity" or "scientism"), rather than capitalism itself. Their analysis, traceable to the philosopher John Dewey and other mid-twentieth-century American progressives as well as to Marcuse and other émigré leftists, held that scholarly detachment prevented intellectuals from assisting the masses in their struggle against the capitalist oppressor. The immediate challenge lay squarely in the realm of epistemology, given that the broader campaign against capitalism could not even begin until scholars recovered a frankly normative conception of knowledge and applied it in the cause of human freedom (ibid.).

Marcuse hardly waxed optimistic about the prospect of such a renewal. OneDimensional Man countered the hopeful, Deweyan tones of the Port Huron Statement with a stark, apocalyptic image of the modern world as a bureaucratic monolith featuring only the tiniest cracks for dissent. Still, it provided a concrete task for critical scholars: tearing away the façade from putatively neutral scholarship. Marcusean critics argued that if moderns suffered from a profound meaning deficit, scholarship divorced from all considerations of meaning could hardly be part of the solution; such knowledge simply reflected the prevailing climate of relativism. But by attacking this very presumption of meaninglessness, especially in its academic guise of value-neutrality, scholars could unleash the tide of critical reason. ${ }^{15}$

This epistemological critique by left scholars meshed well with a growing tendency among radical students to see their target as a hegemonic culture rather than as an

\footnotetext{
${ }^{14}$ Analogously, it is difficult to find concrete political content in the definition of humanists-as those who "believe in the unity of humanity and have faith in the future of man" and thus interpret events "not from the narrow angle of one particular organization or power group, but from the vantage point of humanity"- offered by Erich Fromm, another favorite of student activists in the 1960s. Fromm's later addition of phrases such as "opposition to dehumanization" and "concern with man and the full unfolding of his potentialities" hardly clarified matters. (Fromm 1965a: vii-viii, xii, xi)

${ }^{15}$ As Barzun $(1966,13)$ put the point, modern scholars taught that "there is no difference between meaning and no-meaning."
} 
institutional configuration or a dominant class. The SDS president Carl Oglesby argued in 1965 that corporate liberalism was a full-blown ideology, not just a structural arrangement. As a worldview, he wrote, it "performs for the corporate state a function quite like [that] the Church once performed for the feudal state," namely, "to justify its burdens and protect it from change" (quoted in Kazin 1998: 197). The cultural turn in 1960s radicalism also took shape in the claims of Savio, Farber, and others that students possessed all of the power they needed to take full control of their lives, having in essence forged their own chains by adopting the values they were spoon-fed by society.

\section{Institutional autonomy, redux}

The radical caucuses that emerged in several disciplines after 1967 incubated potent critiques of scholarly detachment. Yet these proved compatible with competing perspectives on the university's orientation toward the larger world. Many advocates of the politics of truth sought to integrate the university more closely with the surrounding society. For example, the historian Theodore Roszak sought to include political activities, such as running for office or organizing a picket line, in disciplinary reward structures, especially at the stage of tenure decisions. After all, Roszak (1968: 36-37) argued, these activities tended to "elevate public debate in our society to a level of intellectual and moral responsibility"surely a key scholarly goal. Meanwhile, Science for the People (SftP) and similar organizations challenged scholarly detachment in its very stronghold, the natural sciences. The SftP activists insisted that "scientific activity in a technological society is not, and cannot be, politically neutral or value-free," given the intimate connection between research advances and policy options. Still, the SftP leaders presumed that scientific knowledge worked, even as they held scientists responsible for the political consequences of their research (Moore 2008; Zimmerman et al. 1972). In this sense they echoed Chomsky's contrast between the "misinformation" of official ideologists and the unvarnished truth of the people. Roszak, too, assumed that scholars could generate universally valid - in the sense of technically reliable - knowledge, though he connected knowledge to action and sought to give the people's truth a place in the public dialogue. ${ }^{16}$

By contrast, those who issued a deeper challenge to neutrality by declaring all truth fundamentally value-laden often pointed back toward institutional autonomy. Believing that scholarly detachment reflected an oppressive, stultifying culture hardly hospitable to professorial activism, many of these radicals sought to rekindle the flame of normativity and nurture the germ of a new culture by insulating the university from outside pressures. A 1969 article by the historians Eugene D. Genovese and Christopher Lasch nicely illustrates the dynamic. Genovese and Lasch called for "a general attack on the instrumental conception of culture," describing the genuine university as the locus of "a quest for

\footnotetext{
${ }^{16}$ To be sure, SftP called for truly consequential changes in the process of scientific research, reaching down to the very processes of grant determination, peer review, and the socialization of students. Nonetheless, its leaders adopted a fairly conventional language of problems and solutions and a corresponding view of knowledge as a matter of facts or techniques, a tool for undermining ideologies. The SftP analysis focused only on what today's interpreters term "problem choice," not "theory choice." To put the point another way, what the SftP activists called "people's science" and contrasted to "class science" was simply scientific truth yoked to the will of the population as a whole. Roszak did not even go this far. Rather, he echoed the less militant "public understanding of science" (PUS) movement, which sought simply to put existing truths in the hands of the people (Roszak 1968: 37). A representative PUS text from that time, written by a Manhattan Project veteran, is Lapp 1965.
} 
meaning, order, and intellectual synthesis demanding ... an atmosphere of unrestricted inquiry and freedom from outside interference." In the long run, they hoped for a system of "publicly financed and institutionally autonomous" universities enrolling far fewer students than the present training grounds for industrial workers. Yet the rise of mass higher education could not be reversed in a day, they allowed. For the time being, Genovese and Lasch called on the Left to "humanize the conditions of apprenticeship" through the "restoration of academic standards." Eventually, they believed, this approach would recreate, under modern conditions, an age-old conception of the university as "a place in which to raise philosophical questions about the very premises of the society it serves." Infusing modern structures with this traditional ideal, Genovese and Lasch's radical university would bring up "the cultural level of the working class as a whole" by producing "a new kind of working-class intellectual": "workers who can think and question and thereby defend their own class interests against those who would keep them docile and passive" (Genovese and Lasch 1969: 22-4, 26).

Genovese and Lasch repeatedly claimed that the academic empowerment of the working class required "the restoration of the unity of learning," not "courses in guerrilla warfare and the crimes of American imperialism." The "ethical and philosophical concerns" characteristic of the arts and humanities would need to once again find a home in the sciences and technical fields, especially "in departments over which positivist and behaviorist perspectives have established an effective tyranny." Genovese and Lasch insisted that all other strategies for liberating workers, such as "campus nihilism," attempts to alter university structures, and calls for "relevance," simply played into "the vulgar instrumentalism underlying bourgeois ideology and practice." The Left would not touch the deeper roots of class oppression in the prevailing "technological anti-culture," they argued, until it "overcomes its neo-Luddism and begins to take itself seriously in the academic world," building "a new cultural synthesis based on the rationalist tradition" (ibid.: 23-4, 267). Only the reunification of learning, Genovese and Lasch argued, could offer the inhabitants of an industrial society what they really needed: not more gadgets or better jobs but rather a coherent, humanly satisfying, and collectively held framework of meaning. ${ }^{17}$

\section{Beyond universal reason}

"The myth of scholarly neutrality, which has now spread from the 'hard' to the 'soft' sciences, must be challenged at every opportunity," Genovese and Lasch (ibid.: 26) declared. Many of their contemporaries echoed the sentiment. The ideal of scholarly detachment came under increasing fire in the 1970s and 1980s as radical theorists pushed their critique of contemporary ills ever farther into the depths of epistemology. In the process, however, key aspects of the program set forth by the likes of Hayden, Goodman, Marcuse, Roszak, and Genovese and Lasch fell away.

As we have seen, these figures sought "objective ethical standards" with which to bind technical fields and social practices alike (ibid.: 26). A surprising number of left

\footnotetext{
17 "Applied to academic matters," Genovese and Lasch stressed, "student power demands are nonsense. If students and teachers are equal in the classroom, then we do not need teachers or classrooms. Here democracy can have only one meaning: it is the teachers' job to guide their students as quickly and surely as possible toward a condition of intellectual equality with themselves." Likewise, the authors rejected the tendency to "flood the universities with unassimilable students," which accelerated "that vulgarization and decay which characterize higher learning at the moment and which are the logical result of neocapitalism in education" (Genovese and Lasch 1969: 24).
} 
activists and scholars, harking back to Enlightenment, Renaissance, and even medieval visions of higher education, shared the lament of the political theorists John H. Schaar and Richard Wolin (1969) that "values are no longer shareable as knowledge" in the modern age. They joined Hayden (2005a: 58) in favoring "real intellectual status," embodied in "the personal cultivation of the mind," over mere social status. And they followed Roszak's (1968: 17) identification of radicalism with "the free market of ideas, the dignity of the individual, the pursuit of intellectual and aesthetic excellence, [and] the value of moral courage." These activists took as their heroes not just political dissidents but also "Socrates and Abelard, Galileo and Spinoza, Voltaire and Pasteur ... and all the others who fought to dignify the life of the mind and to assert the preeminence of the moral virtues" (ibid.). Hayden, Roszak, and many others viewed these moral virtues as true in the sense that they applied universally and thus would win out in truly free processes of intersubjective reasoning.

But as the wave of radical activism crashed on the hard rock of prevailing social practices in the 1970s, the ideal of universal reason lost much of its luster for the academic Left. Roszak's campaign to gain scholarly credit for political work perished in the cradle. Meanwhile, the singular "movement" of the 1960s splintered. Activist scholars cast about for alternative means of turning their work to socially productive ends as they grappled with the thorny problem of conceptualizing multiple axes of social oppression and made an uneasy peace with the academic reward system. Many navigated this complex set of circumstances by extending the critique of scholarly detachment to the ideal of universal reason itself. They found new analytic resources in the work of European theorists disaffected with Marxism's scientism, materialism, and determinism. Rather than seek an objective, universal morality with which to bind technical practices, post-1960s critics have often attempted to bring science and technology under the yoke of values in a different manner, by declaring them thoroughly culture-bound. In other words, they have identified the scope of intersubjective reason as smaller, not larger, than mainstream scholars claim. Busily historicizing those realms of intersubjective truth typically draped with the honorific "cognitive," radical theorists have found less and less of value in Genovese and Lasch's beleaguered "rationalist tradition." 18

Of course, these new critiques of universal reason hardly represented a total break from the intellectual developments of the 1960s. In a nation profoundly shaped by Protestantism and to some extent also by Romanticism, it is hardly surprising that skepticism about claims offered in the name of reason could be found throughout the radical movements of the 1960s, to say nothing of the counterculture. Young radicals stressed the non-cognitive elements of genuine selfhood, presuming that authenticity demanded commitment rather than self-restraint, passion rather than poise. Farber (1970 [1967]) dismissed the intellectual dimension of truth altogether: "Outside class, things are true to your tongue, your fingers, your stomach, your heart. Inside class things are true by reason of authority." Even the comparatively pragmatic FSM contained frankly mystical strains. ${ }^{19}$

In its most extreme form, this critique linguistically banished rationality from the sphere of the human, equating the person with his or her emotional and affective responses

\footnotetext{
${ }^{18}$ Many of the developments addressed here and in subsequent paragraphs are covered in Cusset 2008 and Zammito 2004. See also Hollinger 2001 and Rodgers 2011.

${ }^{19}$ The FSM activist Brad Cleaveland, quoting Henry Miller, told his fellow undergraduates to "live only miraculously, think miraculously, ... die miraculously" (quoted in Kazin 1998: 207).
} 
and identifying rationality as a characteristic of machines, not of organic life. It meshed with a growing tendency among critical scholars to find sources of political inspiration outside the realm of Western elites, especially in the premodern and postcolonial masses. As the counterculture retreated into private spaces, and revolutionary ambitions dimmed, challenges to universal reason took on increasingly intellectualized forms in the academy. They spawned academic theories denying the centrality and perhaps even the salience of cognitive motives in shaping human behavior. Many on the academic left now deemed pure subjectivity a liberating force, especially in its collective, sociological form as "identity."

The turn against universal reason in many precincts of the academic Left helped set the stage for the "culture wars" of the late 1980s and early 1990s. Against the burgeoning critiques of universal reason, prominent liberals and radicals continued to seek a deeper mode of rationality in the form of universally valid moral and aesthetic truths. Chomsky famously insisted, against Michel Foucault and other critics of universalism, that the concept of truth must anchor any viable progressive movement. Other universalists on the left attacked emerging forms of "identity politics." Genovese and Lasch (1969: 24) ventured into politically ambiguous territory, seeking alternative foundations for radical politics in America's "republican tradition" and the emerging framework of communitarianism. Finding the self-proclaimed academic champions of the people decidedly unfriendly to "intellectual standards and hard work," Genovese and Lasch discovered points of commonality with the traditionalist Right, now numbering David Horowitz among its ranks. So, too, did Searle in his campaigns against "political correctness," rent control, and other policies of the Left. In the subsequent "science wars" of the mid-1990s, many additional leftists who dismissed the anti-political correctness discourse but refused to relinquish the possibility of a progressive form of truth found themselves suddenly cast in the role of establishmentarians. Paul R. Gross and Norman Levitt, who emerged as leading defenders of science and rationality in that era, were unreconstructed socialists. Feminists, too, divided over the "science question" in the 1990s (Harding 1986). ${ }^{20}$

Through it all, however, the broad ideal of institutional autonomy has retained remarkable strength. In the 1960s, as we have seen, calls for courageous, socially engaged scholarship — “socially aggressive inquisitiveness," as Roszak (1968: 7) termed it —often accompanied criticism of Kerr's vision of the university as a faithful servant of society. Since then, however, institutional autonomy has found many vocal defenders on the academic left. Activists no longer seek credit for picketing outside local hospitals or running for school board president; the entrenched tenure system quickly shut down that outburst of heterodoxy as the caucuses folded themselves back into the disciplines. Indeed, many radical scholars join their culture-warrior opposites in defending the ideal of an institutionally autonomous, though normatively inclined, university. Some assume that the academy determines the cultural tone and thereby the institutional structures of the surrounding society. Others note that the resurgence of the free-market Right and the rise of the Christian Right have put the university in precisely the embattled position that Hofstadter thought it occupied. A few, led by the Frankfurt school-inspired Russell Jacoby

\footnotetext{
${ }^{20}$ Hofstadter and Goodman both died in 1972, before the full flowering of today's challenges to universal reason. However, they decried the precursors. Goodman (1970), profoundly disturbed by the counterculture and by the New Left's revolutionary tactics and turn away from the possibility of truth, described himself as a "neolithic conservative" in the late 1960s. Meanwhile, Hofstadter continued to view himself as a critic of liberalism from within (Brown 2006: 191).
} 
(1987), deem the universities themselves incapable of providing the institutional autonomy that "independent intellectuals" once carved out in the interstices of the marketplace.

Yet it remains to be seen whether a mode of scholarly activism centered on the ideal of institutional autonomy will prove more effective than its 1960s precursors. Already in 1966 the former Marxist and future neoconservative Irving Kristol (1966: 3-4), then in his liberal phase, decried what he called the "neo-isolationist" view of the scholar's public role. He found among many academic radicals a "conservative and traditionalist," even nostalgic, conception of intellect. Kristol saw in that theory a mere sleight of hand that magically turned the uncomfortable fact of powerlessness into the virtue of critical distance. ${ }^{21}$ Was Kristol right? Or have the writings of a theorist such as Foucault contributed more to social change than the activism of a Chomsky or a Howard Zinn? Forty-eight years after the FSM erupted, the jury is still out.

\footnotetext{
${ }^{21}$ Kristol called for "distinctions between different kinds of theory and different kinds of practice" leading to different relations between groups of scholars and practitioners. Whereas the social sciences produced technical knowledge for various external constituencies, he specified, the arts and humanities worked "to question or affirm the legitimacy of a society's basic institutions, to criticize or amend the original assumptions on which political life proceeds," thereby playing a key role in "defining the moral quality of our society" (Kristol 1966: 5-6).
} 


\section{References}

Anonymous. (1971 [1969]) "A dialogue on classroom disruption," in Immanuel Wallerstein and Paul Starr (eds.) The University Crisis Reader, Vol. II: Confrontation and Counterattack. New York: Vintage: 57-61.

Barzun, Jacques (1964) Science: The Glorious Entertainment. New York: Harper \& Row. (1966) "Science as a social institution." Proceedings of the Academy of Political Science 28 (2): 3-14.

Bloland, Harland G., and Sue M. Bloland (1974) American Learned Societies in Transition: The Impact of Dissent and Recession. New York: McGraw-Hill.

Brick, Howard (1998) Age of Contradiction: American Thought and Culture in the 1960s. New York: Twayne.

(2006) Transcending Capitalism: Visions of a New Society in Modern American Thought. Ithaca: Cornell University Press.

Brown, David S. (2006) Richard Hofstadter: An Intellectual Biography. Chicago: University of Chicago Press.

Brubacher, John S., and Willis Rudy (1997) Higher Education in Transition: A History of American Colleges and Universities, 4th ed. New Brunswick, NJ: Transaction Publishers.

Calvert, Greg (1970 [1967]) "In white America: radical consciousness and social change," in Massimo Teodori (ed.) The New Left: A Documentary History, 412-18. London: J. Cape.

Chomsky, Noam (1968 [1967]) "The responsibility of intellectuals," in Theodore Roszak (ed.) The Dissenting Academy. New York: Pantheon: 254-98.

Cusset, François (2008) French Theory: How Foucault, Derrida, Deleuze, and Co. Transformed the Intellectual Life of the United States. Minneapolis: University of Minnesota Press.

Davidson, Carl (1971 [1967]) “Toward institutional resistance," in Immanuel Wallerstein and Paul Starr (eds.) The University Crisis Reader, Vol. II: Confrontation and Counterattack. New York: Vintage: 129-38.

Evans, M. Stanton (1961) Revolt on the Campus. Chicago: Regnery.

Farber, Jerry (1970 [1967]) “The student as nigger," in The Student as Nigger: Essays and Stories. New York: Pocket: 90-100.

Free Speech Movement (1965) "We want a university," in Seymour Martin Lipset and Sheldon S. Wolin (eds.) The Berkeley Student Revolt: Facts and Interpretations, 208-216. Garden City, NY: Anchor Books.

Freeland, Richard M. (1992) Academia's Golden Age: Universities in Massachusetts, 19451970. New York: Oxford University Press.

Freeman, Jo (2004) “The Berkeley Free Speech Movement,” in Immanuel Ness (ed.) 
Encyclopedia of American Social Movements, 1178-1182. Armonk, NY: Sharpe Reference.

Fromm, Erich (1965a) "Introduction," in Socialist Humanism: An International Symposium. Garden City, NY: Doubleday: vi-xiii.

(1965b) Socialist Humanism: An International Symposium. Garden City, NY: Doubleday.

Geary, Daniel (2009) Radical Ambition: C. Wright Mills, the Left, and American Social Thought. Berkeley: University of California Press.

Genovese, Eugene D., and Christopher Lasch (1969) "The education and the university we need now." New York Review of Books, October 9.

Gitlin, Todd (1993) The Sixties: Years of Hope, Days of Rage. New York: Bantam Books.

Goodman, Paul (1962) The Community of Scholars. New York: Random House.

_ (1964) Compulsory Mis-Education. New York: Horizon Press.

_ (1965) “Thoughts on Berkeley.” New York Review of Books, January 14. (1970) New Reformation; Notes of a Neolithic Conservative. New York: Random House.

Harding, Sandra G. (1986) The Science Question in Feminism. Ithaca: Cornell University Press.

Harrington, Michael (1997 [1962]) The Other America: Poverty in the United States. New York: Simon \& Schuster.

Hayden, Tom (2005a) The Port Huron Statement. New York: Thunder's Mouth Press. - (2005b) "The way we were and the future of the Port Huron Statement," in The Port Huron Statement. New York: Thunder's Mouth Press: 1-42.

Herberg, Will (2008) "Prologue: What is the moral crisis of our time?" in Mark C. Henrie (ed.) Arguing Conservatism: Four Decades of the Intercollegiate Review. Wilmington, DE: Intercollegiate Studies Institute: 1-7.

Herman, Ellen (1995) The Romance of American Psychology: Political Culture in the Age of Experts. Berkeley: University of California Press.

Hofstadter, Richard (1968) "The 214th Columbia University commencement address," American Scholar 37 (4): 583-9.

Hollinger, David A. (2001) "The Enlightenment and the genealogy of cultural conflict in the United States," in Keith Michael Baker and Peter Hanns Reill (eds.) What's Left of Enlightenment? A Postmodern Question, 7-18. Stanford, CA: Stanford University Press.

Horowitz, Daniel (2004) The Anxieties of Affluence: Critiques of American Consumer Culture, 1939-1979. Amherst: University of Massachusetts Press.

Hutchins, Robert M. (1967) "The issues," in The University in America. Santa Barbara, CA: Center for the Study of Democratic Institutions: 4-8. 
(1970) “U.S. Universities Don't Know What They're Doing or Why, Robert M. Hutchins Says.” Chronicle of Higher Education (March 9).

Isserman, Maurice, and Michael Kazin (2008) America Divided: The Civil War of the 1960s, 3rd ed. New York: Oxford University Press.

Jacoby, Russell (1987) The Last Intellectuals: American Culture in the Age of Academe. New York: Basic Books.

Jamison, Andrew, and Ron Eyerman (1994) Seeds of the Sixties. Berkeley: University of California Press.

Kazin, Michael (1969) “Some notes on S.D.S.” American Scholar 38 (4): 644-55.

(1998) The Populist Persuasion: An American History, rev. ed. Ithaca: Cornell University Press.

Kerr, Clark (1963) The Uses of the University. Cambridge, MA: Harvard University Press. (1964) "Society and the status quo: The individual and the innovative society." Science n.s. 144 (3615): 164-165.

Kristol, Irving (1966) “The troublesome intellectuals.” Public Interest 2: 3-6.

Lapp, Ralph E. (1965) The New Priesthood: The Scientific Elite and the Uses of Power. New York: Harper \& Row.

Leslie, Stuart W. (1993) The Cold War and American Science: The Military-IndustrialAcademic Complex at MIT and Stanford. New York: Columbia University Press.

Marcuse, Herbert (1969 [1965]) "Repressive tolerance," in Robert Paul Wolff, Barrington Moore Jr., and Herbert Marcuse, A Critique of Pure Tolerance. Boston: Beacon: 81117.

— (2002 [1964]) One-Dimensional Man: Studies in the Ideology of Advanced Industrial Society. New York: Routledge.

Matson, Floyd W. (1964) The Broken Image: Man, Science and Society. New York: G. Braziller.

Maxwell, W. David (1969) "Some dimensions of relevance," AAUP Bulletin 55 (3): 33741.

McCaughey, Robert A. (2003) Stand, Columbia: A History of Columbia University in the City of New York, 1754-2004. New York: Columbia University Press.

McCumber, John (2001) Time in the Ditch: American Philosophy and the McCarthy Era. Evanston: Northwestern University Press.

Miller, James (1994) Democracy Is in the Streets: From Port Huron to the Siege of Chicago. Cambridge, MA: Harvard University Press.

Mills, C. Wright (1956) The Power Elite. New York: Oxford University Press. (1959) The Sociological Imagination. New York: Oxford University Press.

Moore, Kelly (2008) Disrupting Science: Social Movements, American Scientists, and the Politics of the Military, 1945-1975. Princeton: Princeton University Press. 
New York Times (1965) "Sociology for what?," September 21.

Reisch, George A. (2005) How the Cold War Transformed Philosophy of Science: To the Icy Slopes of Logic. New York: Cambridge University Press.

Reuben, Julie A. (2000) "The university and its discontents." Hedgehog Review 2 (3): 7291.

(2002) "The limits of freedom: student activists and educational reform at Berkeley in the 1960s," in Robert Cohen and Reginald E. Zelnik (eds.) The Free Speech Movement: Reflections on Berkeley in the 1960s, 485-510. Berkeley: University of California Press.

Riesman, David, in collaboration with Reuel Denney and Nathan Glazer (1950) The Lonely Crowd: A Study of the Changing American Character. New Haven, CT: Yale University Press.

Roberts, Jason Daniel (2007) "Disillusioned radicals: the intellectual odyssey of Todd Gitlin, Ronald Radosh, and David Horowitz." PhD diss., George Washington University.

Rodgers, Daniel T. (2011) Age of Fracture. Cambridge, MA: Belknap Press.

Rossinow, Doug (1998) The Politics of Authenticity: Liberalism, Christianity, and the New Left in America. New York: Columbia University Press.

(2002) "Mario Savio and the politics of authenticity," in Robert Cohen and Reginald E. Zelnik (eds.) The Free Speech Movement: Reflections on Berkeley in the 1960s, 533-551. Berkeley: University of California Press.

Roszak, Theodore (1968) “On academic delinquency,” in Roszak (ed.) The Dissenting Academy. New York: Pantheon: 3-42.

Schaar, John H., and Richard Wolin (1969) "Education and the Technological Society." New York Review of Books, October 9.

Schrecker, Ellen (1986) No Ivory Tower: McCarthyism and the Universities. New York: Oxford University Press.

Searle, John R. (1968) “A Foolproof Scenario for Student Revolts,” New York Times, December 29.

(1971) The Campus War: A Sympathetic Look at the University in Agony. New York: World.

Wang, Jessica (1999) American Science in an Age of Anxiety: Scientists, Anticommunism, and the Cold War. Chapel Hill: University of North Carolina Press.

Whyte, William H. (1956) The Organization Man. New York: Simon and Schuster.

Zammito, John H. (2004) A Nice Derangement of Epistemes: Post-Positivism in the Study of Science from Quine to Latour. Chicago: University of Chicago Press.

Zimmerman, Bill, Len Radinsky, Mel Rothenberg, and Bart Meyers (1972) "Towards a science for the people," ist-socrates.berkeley.edu/ schwrtz/SftP/Towards.html, accessed on July 7, 2009. 